第71回日本内科学会瀞演会 (1974年)

\title{
シンポジウム 消化管ホルモン
}

（7）消化管ホルモンのヒト消化管運動調節作用 上臨床的意義

山班大学医部部内科

石川 誠

東北大学医学部山断内科

石森章

\section{SYMPOSIUM ON GASTROINTESTINAL HORMONES \\ (7) A CLINICAL STUDY OF REGULATION ON MOTILITY OF DIGESTIVE TRACT BY GASTROINTESTINAL HORMONES}

\author{
Makoto IshikawA, M.D. and Akira Ishimori, M.D. \\ Medical Department of Prof. S. Yamagata, \\ Tohoku University School of Medicine, Sendai
}

\section{I. 粕 言}

消化管の運動機能の面から, 消化管ホルモン相 互間の協調作用を検討すると共化，各種の疾患あ るいは，障害においては、この関係がどの様な変 化をこうむるかを特に，ガストリン拈よびセクレ チンの相互作用について, 食道, 胃, S 状結腸の 内圧括上び $\mathrm{S}$ 状結晹筋電図測定ならびに血中ガス トリンの定量, 胃液 $\mathrm{PH}$ 測定など病態生理学的見地 から模討を加えたので報告する。

\section{II. 対象およひ方法}

1. 対象：健常者敊上び山形内科に入院した 逆流性食道炎・食道裂孔へルニア・胃溃瘍・十二 指腸溃瘍扎よび，便通異常者を対象とした。

2. 食道内圧測定法：Open-tip法により内径 $1.5 \mathrm{~mm}$, 長さ $1 \mathrm{~m}$ で先端に直径 $1.5 \mathrm{~mm}$ 側孔を有 するポリェチレン管 3 本を束ねたものを用い，低 圧力用トランスジューサーに接続し，ペン書きオ ッシログラフで記録した，1本の誘導管は胃液吸 引，或いは，胃内の各種刺激剤注入に用いた。検 查は，早期空腹時，X線透視下に誘導管を食道・
胃接合部に固定し，トランスジューサーの位置を 調整した後行なつた。

3. 胃内王测定法：早朝品腹時，二重管に付 けたバルーンを胃内に插入し，透視下に，前庭部 にあることを確加な後, $50 \mathrm{ml}$ の空気を注入し て，バルーンを膨らませ，中仼门用トランスジュ ーサーに接続して，内止曲線を記録した。同時 に，二重管の一方方らは経時的に少量の胃液を採 取して，pH在測定した。

4. S 状結腸筋電図およ゙゙内圧測定法： ゴム バルーンの表面に直径 $300 \mu$, 極間距離 1 mのつ゚ ラチナ電極を固定したゴムバルーン電極を直腸鏡 誘導下に肛門より約 $25 \mathrm{~cm}$ 插入した後, $60 \mathrm{ml}$ の空 気を注入して，バルーンを膨らをせ，電極を固定 し，筋電図扣よび内任曲線を同時記録した。な お，胃㧍よび $\mathrm{S}$ 状結腸の内圧曲線或いは，筋電㘠 所見の表現にあたつては， motility index 占を採用 し，単位時間内に出現するそれぞれの波型の振幅 と接続時間との積を求め，これらの和を単位時間 て除して求めた。 
5. 血中がストリン濃度測定： C.I.S.がスト リン測定用キット艺用い, dextran-coated charcoal 法2)により測定した。

\section{III. 成 績}

1. 食道・胃接合部括約能

1）ガストリンと健常者：健常者に拈ける基 礎的検討においては，ガストリン様テトラペプチ ト (AOC-TG) の投与が食道・胃接合部圧の上昇 をるたらし，セクレチンは逆に低下をもたらすこ とが確かめられた。

2）食道炎：各種doseのAOC-TGK対する括 約正の反応を健常者との比較に拉いて㭘討した。

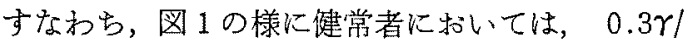
$\mathrm{kg}$ から $0.5 \gamma / \mathrm{kg}$ 之増量するにつれて，括約圧の上 昇する事が琹められたが，逆流性食道炎に持いて は, dose-responseが逆転し，投与量の増加が却っ て，括約圧の減少をもたらす場合もあることが認 めら机た。すなわち，高度の逆流性食道资症例飞 ついて各種の薬剤に対する括約能の反応を検討し たところ，AOC-TG $0.5 \gamma / \mathrm{kg}$ 静注は，括約压の 上昇をもたらさず，逆に低下の傾向さ兄認められ

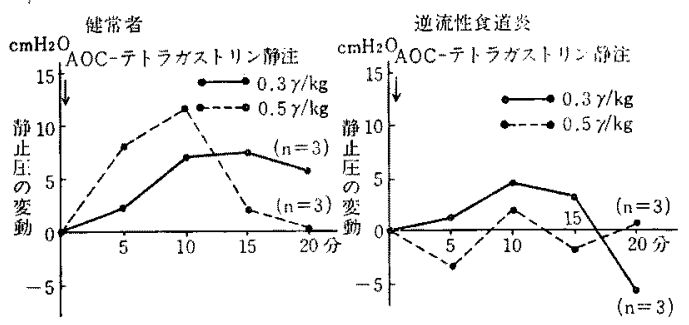

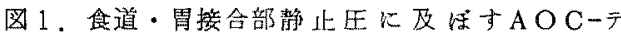
トラガストリンの影掣

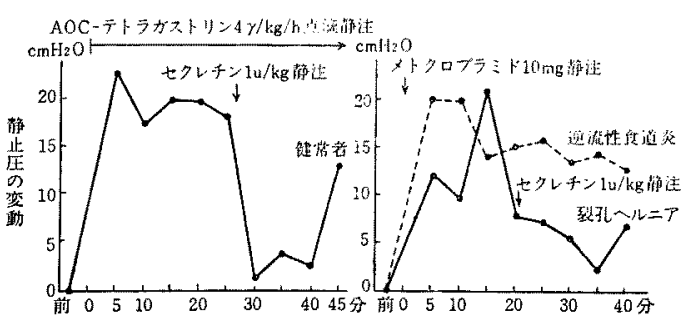

图2，食道・胃接合部静止在に及ぼすセクレチン の影隌 た.しかるに、メトクロプラミド10m静注は， 括約圧の大幅な上昇をもたらし，極めて対照的な 所見を呈することが認められた。よつて，以上の 样な所見を総合すると，这流性食道炎にみられる 食道・胃接合部の括約能の障害は，主としてガス トリンに対する感受性の低下に基づくるのであ り，他の薬剤に対する反応性は比較的よく保持さ れている事を示嘫するむのと考学られた。

3）七クレチンと食道・胃括約能：七クレチ ンの食道・胃接合部の括約機能に対する影響をみ ると図 2 の様に，ガストリンにより高められた括 約圧は，七クレチン投与により著明に低下する事 が認められるが，図右の様に、メトクロプラミト゚

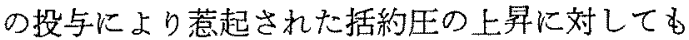
抑制効果が認められる。よつて，セクレチンの括 約圧低下作用は，ガストリンに対してのみ特異的 に拮抗するのではなく，他の刺激昘比よる括約圧 の上昇に対しても抑制効果を示すことが示哠され る.

\section{2. 胃の運動}

健常者に执いては，ガストリンは，胃の運動に 促進的に，セクレチンは，抑制的に作用すること が認められたが，胃潰瘍と十二指腸潰瘍との間に 扎ける運動の相巽の有無を検討するため，外部よ りAOC-TGを投与し，胃内圧曲線に及ぼす影響を 健常者と消化性潰汮患者について比較模討する 之，図 3 の様に，健常者と消化性潰瘍患者との間 には、とくに相異は認められなかつた。また，右の
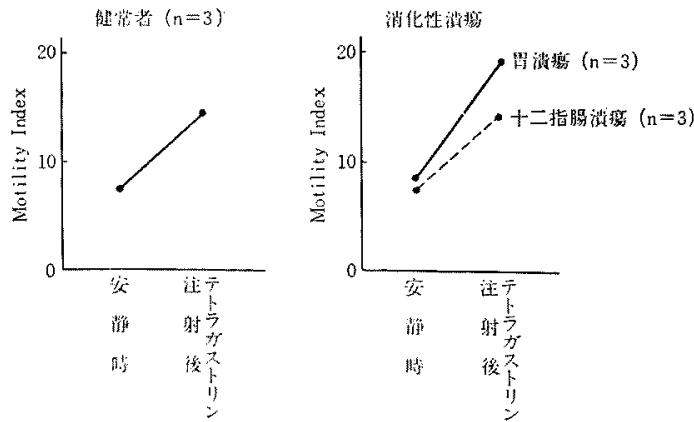

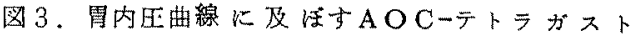
リン $(0.3 \gamma / \mathrm{kg}$ 竫注) の影暗 


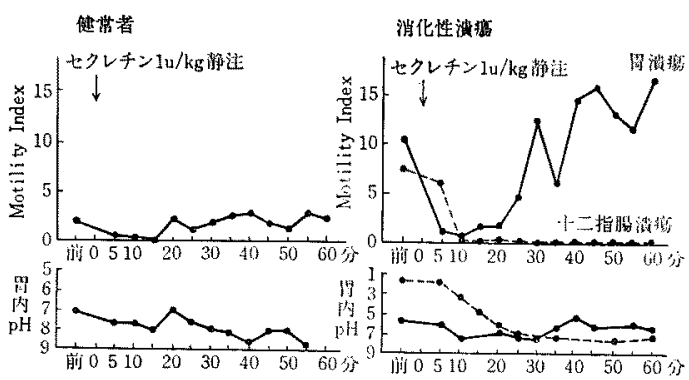

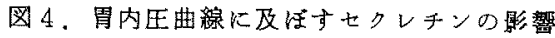

様に胃潰湟と十二指腸潰瘍との間にも相違は認め られなかつた。セクレチンの胃内圧に及ぼす影響 を検討すると，図40様に，健常者拉よび胃潰湶 患者では，セクレチンによる胃内圧の低下が一 過珄にとどょるのに対し，十二指腸潰瘍において は，胃内压の低下が，高度かつ，長時間に亘り観 察された症例も認められた。

\section{3. $\mathrm{S}$ 状結腸運動}

1）健常者： S 状結腸の内正は，ガストリン でもセクレチンでも高められる事が認められた。

2）便通異常者：便通異常者に打けるS 状結 腸内圧と消化管ホルモンとの関保を検討すると， 図 5 の様にAOC-TG $1.0 \gamma / \mathrm{kg}$ の静注は，健常者拉 よび便通異常者のいず机においても内和の上昇を もたらしたが，その程度は，健常者が最も強く， 便秘，下痢の順に減少する傾向が認められたが有 意差はなかつた。

内因性ガストリンについて同様な検討を加亲る ため，食物拱取時に括けるS 状結腸内圧を検討乙
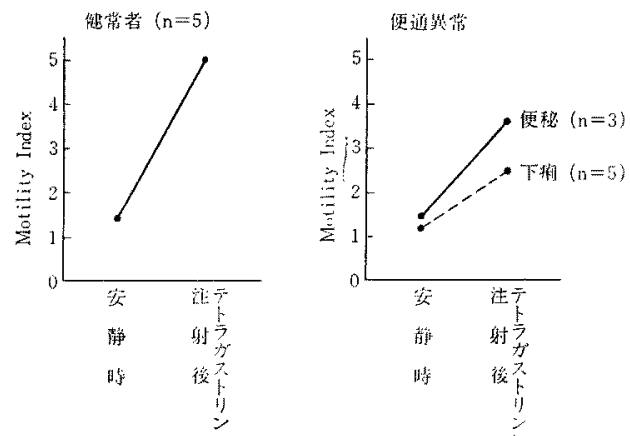

図 5.S 状結䭪内正曲線飞及ぼすAOCーテトラ ガストリン（ $1.0 \gamma / \mathrm{kg}$ 静注）の影缷

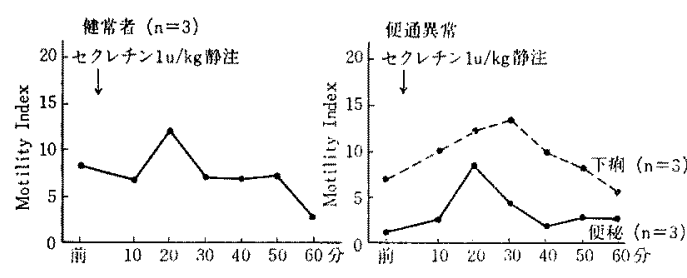

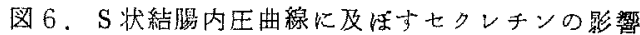
た成績によると，肉エキスの摂取により血中ガス トリンは，健常者に打いても，便通異常者におい ても同様に上昇し，乙れに対して，S 状結腸内圧 の上昇傾向が認められた，肉ェ丰投与後の内王 の上昇は健常者に比较して便通堅常者に打いて は，一過性ながら一見，より高值を示したが，最 高上昨度を比較したところによると，健常者と便 通異常者との間に有意の差は認められなからた。 ヒクレチンのS 状結腸内压に及ぼす影響を，健常 者と便通異常者との間で比傚すると，図6の様に， セクレチン $1 \mathrm{u} / \mathrm{kg}$ 静注は両者において，一過性 の内压上昇をもたらすが，下痢の患者比いて， より長時間に亘り持続することが注目された。

\section{IV. 考 案}

消化管運動之消化管ホルモンとの関係を検討す るにあたり，食道・胃接合部の括約機能，胃運動 抢よび，S 状結腸運動をとり范げ，相互に拮抗作 用のあることが知られているが，ガストリンとセ クレチンが，これらの運動機能に対してどの様な 影響を及ぽし，また，各種疾患或いは障害時にど の様な変化が起こるかを検討した。

食道・胃接合部の括約機能は，食道への酸性胃 内容物の逆流を防止し，胃液の強力な消化力か 食道粘膜を防御していると考元られるが，ガス卜 リンは，括約圧の上昇，七クレチンは，低下をむ たらす事 ${ }^{324}$ が，本研究に打いても確かめられた。 しかし，健常者に扣いては外来投与のAOC-TGの 増量に対して括約压は，正のdose-responseを示し たが，逆流性食道炎に扣いては，負の反応を示す 症例のあることが誌められた。さらに，逆流性 食道炎に损いては，AOC-TGK対する括約圧の著 明な低下があるのにもかかわらず，メトクロプラ 
ミドに対しては，かなりの反応を保持している症 例のむ吉事も認められた。この様な所見は，逆流 性食道炎沉执いては，ガストリンに対する食道・ 胃接合部の感受性が缸害され，暴常な反応を呈主 る様になつている場合がある事を示唆するものと 考えられる，这流性食道炎の任中ガストリンは特 に，健常者対照群と相違を示さなかつたが，この 事は，Achalasiaの場合のように䓹道・胃接合部 の障害が逆流性食道炎の発生にとつて最も重要で あり，ガストリン内分泌㙨序は，第二義的な意義 にとどまることを示すものと考觉られる。机た， 上述の成績は, メトクロプラミドによる逆流性食 道炎の治療 ${ }^{677}$ の妥当性を支持主るすのと考光ら 机る。

セクレチンがAOC-TGだけでなく，メトクロプ ラミド刺澈による括約圧の上䒜に対して抑制効果 を示した事は，七クレチンが，ガストリンに対す る単純な拮抗作用を有するだけではなく，その他 に串複雑な作用機序を有している事を示唆してい るものと考えられる。すなわら，ガストリンは， 節後線維を刺激してアセチルコリンの遊離を促 し，括約王の上昇を来たす事が指摘されている が，セクレチンは，他の抑制機序も有することが 考它られる。

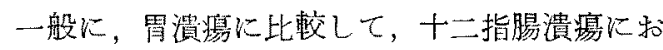
ける胃運動の九進が認められている の成緷では，AOC-TGに対する胃運動反応にかん して両者の間に特に著明な差を認めなかつたが， セクレチンに対しては，十二指腸潰瘍に沶いて， 高度から，持続性の運動低下を示症例が認めら れ，胃潰瘍之十二指腸潰瘍との間に認められる胃 運動の相違の背後には複雑な機序が存在し，他の 消化管ホルモンの関与している可能性も考兄られ

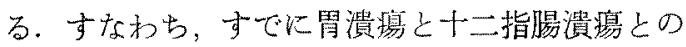
間には，十二指腸粘膜内に含を机る七クレチン様 活性にかえして相違が認められ，十二指腸潰瘍に 扣いてょり高い活性が認められている ${ }^{10)}$ 。っ て，十二指腸潰㾮患者に执いてみられたせクレチ ンによる渚明な運動抑制は, 酸分泌の元進を特徵
とする十二指腸潰癔に招いて，酸性胃内容物の十 二指腸への排出を遅延させ，その結果アルカリ性 䏽液による酸の中和が効果的に行なわれることを

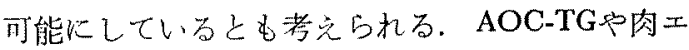
キス投与による内因性ガストリンの刺激やセクレ チン投与では，S 状結腸の運動は，健常者も，便 通異常者も九進を示したことは注目すべきである が，とくに，便通異常者では，これらのホルモン に対する感受性の翼常が第一義的に若起され，便 通異常が発生するものと考えられた．以上のこと か心，逆流性食道炎，消化性潰惶，および便通異 常者では，いずれる各器官に蚂けるこれら消化管 ホルモンに対する感受性の障害があるものと考克 られた。

\section{V. 結 論}

消化管ホルモンの消化管連動に対する相互協調 作用，とくに逆流性食道炎，消化性潰瘍，便通異

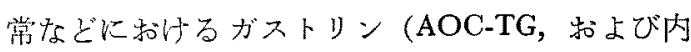
因性ガストリン)，セクレチンの影響について，内 王曲線，筋電図などを測定して鍫討し，次のよう な結論恚之た。

1）健常者においては，ガストリンは食道・胃 接合部の括約筋，胃運動就よび $\mathrm{S}$ 状結腸部の運動 ふ京進し，セクレチンは，前二者の運動を抑制 し， S 状結腸の運動を促進する.

2）逆流性食道炎では，他の楽剤よりも，とく にガストリンに対する感受性の低下の存在が示唆 される。

3）十二指腸潰場患者では，セクレチンによつ て著しい運動抑制効果がみられる場合がある。

4）便通異常には，多くの因子が関与し，その 機序は複雑ではむるが，逆流性食道炎，消化性潰 瘍などに打けると同様に，ガストりン，七クレチ ンに詨す方感受性の障彗方第一義的に存在するも のと思加る。.

㺟同矿究者

高橋恒思，長崎明男，山形 迪，三浦義邦

\section{文献}

1) Chaudhary, N.A. \& Truelove, S.C.: Gastro- 
enterology 40: 1, 1961, -2) Yallow, R.S. \& Berson, S.A.: Gastroenterology 58: 1, 1970. -3) Giles, G.R. et al.: Gut 10: 730, 1969. -4) Cohen, S. \& Lipshutz, W.: J. clin. Invest. 50: $449,1971$. -5) Cohen, S, et al.: J. clin. Invest. 50: 1241, 1971. -6) Stanciu, C. \& Bennett,
J.R.: Gut 14: 275, 1973, -7) Dilawari, J.B. \& Misiewicz, J.J.: Gut 14: 380, 1973. -8) Li. pshutz, W. et al.: Gastroenterology 61:454, 1971. -9) Drgstedt, L.R.: Rev. Internat. Hepat. 16: $615 ， 1966 .-10)$ 石森筈，建部简明：第15回日 本消化器病学会秋季大会シンポシウム, 1973 . 